\title{
Predictors of Complain Behaviour among Mobile Telecommunication Network Consumers
}

\author{
Anyanwu Hilary Chinedu ${ }^{1}$, Sharifah Azizah Haron ${ }^{1,2} \&$ Syuhaily Osman ${ }^{1}$ \\ ${ }^{1}$ Department of Resource Management and Consumer Studies, Faculty of Human Ecology, Universiti Putra \\ Malaysia, Selangor Darul Ehsan, Malaysia \\ ${ }^{2}$ Social Gerontology Lab, Malaysian Research Institute on Ageing, Universiti Putra Malaysia, Selangor Darul \\ Ehsan, Malaysia \\ Correspondence: Anyanwu Hilary Chinedu, Department of Resource Management and Consumer Studies, \\ Faculty of Human Ecology, Universiti Putra Malaysia, Selangor Darul Ehsan, Malaysia. E-mail: \\ chineduhilary@yahoo.com
}

Received: December 20, 2016

Accepted: January 13, 2017 Online Published: January 16, 2017

doi:10.5539/ijms.v9n1p119

URL: http://dx.doi.org/10.5539/ijms.v9n1p119

\begin{abstract}
This research paper sought to empirically determine the predictors of consumer complain behaviour. High prevalence of anomalies with mobile telecommunication network services without a lasting solution emphasized the significance of the present study. Hawkins, Best, \& Coney (2004) consumer complain behavioural framework was used as the study's theoretical background. It was a quantitative study which employed a cross-sectional survey. A total of 385 respondents within Festac town in Nigeria were selected stratifiedly for the study. Descriptive analysis showed that $64.9 \%$ of the respondents are passive while $35.1 \%$ are active complainers. Regression analyses revealed that six demographic variables explained $4.9 \%$ variance on complain behaviour while dissatisfaction explained additional $10 \%$ variance on complain behaviour. It further indicated that three control measures were significant, with dissatisfaction $(\beta=-.33, \mathrm{p}<.001)$, religion $(\beta=.12, \mathrm{p}<.05)$ and level of income $(\beta=.11, \mathrm{p}<.05)$. Dissatisfaction is an insubvertable factor of complain behaviour regardless of consumers' religious affiliation and level of income. Firms should try to alleviate dissatisfaction, encourage active complain, and pay more attention to consumers' religiosity and level of income since these variables influence complain behaviour.
\end{abstract}

Keywords: consumer complain behaviour, mobile telecommunication network, MTN consumers, dissatisfaction

\section{Introduction}

Consumer complain behaviour $(\mathrm{CCB})$ has received a great attention from practitioners and scholars in marketing literature (Mensah, 2012; Nimako, 2012). Despite that, researchers remain divisive on the factors that aggravate CCB. For instance, some authors have suggested that dissatisfaction is the cause of consumer complain behaviour (Grace, Anna, \& Ada, 2016; Heung \& Lam, 2003). On the contrary, Ridzwan et al. (2013); Reiboldt (2003); Huefner \& Hunt (2000); Reidenbach \& Robin (1990) asserted that demographic variables or/and interpersonal factors causes CCB more. CCB occurs because of product/service quality that is perceived as satisfactory or below expectation (Grace, Anna, \& Ada, 2016); is strongly related to consumer dissatisfaction and that dissatisfied consumers are more likely to vent their dissatisfaction through complaining (Liu, Kang, Bai, \& Zhang (2006). These mixed assertions necessitate a pragmatic investigation into the major predictors of CCB.

Going by the flaws within mobile telecommunication network (MTN) services, some consumers have adopted a passive complain behaviour while few have chosen to be active complainers. It is pertinent to note that "high tariff and network fluctuations with MTN services" (Donu, 2011) and "unsubscribed and unsolicited caller tunes with charges" (Timothy, 2015) have made Nigerian consumers feel highly ripped-off by MTN. For the purpose of these great concerns among consumers, this research paper has two objectives, namely; (i) to evaluate the complain behaviour of MTN consumers. (ii) To determine the major predictors of complain behaviour.

Extant studies on CCB have created a platform on the likely causes of CCB. Nonetheless, several studies such as Grace, Anna, \& Ada (2016); Ridzwan et al. (2013); Nimako (2012); Lui, Kang, Bai, \& Zhang (2006) continued on varied opinions on the major causes of CCB. Moreover, there has been no study that investigated the 
complain behaviour of MTN consumers in Nigeria. Hence, there is a gap in consumer literature and on complain behaviour of telecom consumers in Nigeria. As such, this research paper sought to clarify the varying opinions of previous researchers on the subject matter, provide an insight on the complain behaviour of MTN consumers and establish a pragmatic evidence on the causes of CCB by hypothesizing that; $\mathrm{H}_{0}$ (i) demographic variables have no significant effect on CCB. (ii) Dissatisfaction has no significant effect on CCB after controlling the effects of demographic variables.

\section{Literature Review}

Complain behaviour is a crucial phenomenon for both scholars and business leaders and must be understood because of its role on consumer's perceptions of the service experience (Tronvoll, 2008); act of identifying and dealing with the analysis of all the aspects involved in consumer reaction to a product/service failure and the consequent perceived dissatisfaction (Sergio, 2007); all the actions that are caused by perceived dissatisfaction in a purchase episode (Mowen, 1993); and any personal feeling to demand for compensation in a marketing exercise (Bearden \& Mason, 1984).

Jacoby \& Jaccard (1981) are among the first researchers to define CCB. Based on their concept, CCB is any individual action that involves negative communication in respect to a product or service either to the producer or marketer of that product/service or to a third-party organisational entity. CCB occurs because of service quality that is perceived as satisfactory or below expectation (Grace, Anna, \& Ada, 2016).

The proposition that complain behaviour is mainly a product of disagreement between manufacturers/service providers and consumers after comparing a product or service performance with perceived expectation is not in doubt. Notably, CCB is also triggered by tremendous level of satisfaction in certain cases, such as when consumers offer useful responses to service providers. Complain could crop up as a result of defective product or poor service, unfulfilled expectations in service encounter, or an unfulfilled promise given by a manufacturer or service provider (Grace, Anna, \& Ada, 2016). Research has shown that some consumers complain for reasons other than seeking redress (see Singh, 1988).

In line with Singh (1988) observation, the definitions of CCB in the present study are in two folds. Mowen (1993)'s definition and that of Jacoby \& Jaccard (1981) are similar, although the former did not stress on the use of a third party but actions due to a product/service is common in them. It means that the actions may or may not be for reward or compensation. Another fold of CCB definition is from Bearden \& Mason (1984); and Grace, Anna, \& Ada (2016). These authors fell short of projecting their definitions in a more accommodating way as to incorporate complaining for reasons other than seeking redress. It should be understood that some consumers are clamouring for recognition from service providers, as such, they complain even when they are satisfied. Some consumers may still complain even though they are satisfied (Nimako, 2012); and satisfied consumers complain to provide useful service quality feedback to providers (Liu, Kang, Bai, \& Zhang, 2006). Consumers also complain for reasons other than monetary compensations, refund, or apology from the firm. Consumers that complain for reasons other than compensation or apology are doing so for social recognition, assassination of organizational image, and/or deterrence to other consumers aimed at grounding the operations of such firms. Consumers in this category are agitators.

\subsection{Theoretical Background}

The present research paper adopted Hawkins, Best, \& Coney (2004) consumer behavioural framework as a theoretical background to help in the understanding and explanation of consumer complain behaviour (CCB). Hawkins, Best, \& Coney (2004) facilitated the classification of several CCB into two major groups, namely; unresponsive and responsive behaviours. According to the authors, unresponsive complaining channels are informal consumer behaviours such as negative word of mouth (NWOM) and mumbling. Being unresponsive entails the consumer to live with the dissatisfaction situation. When a consumer resorts to live unresponsive in his/her discontent, it gives no positive attitude or remark about the firm or brand. This is also known as passive life. Unresponsive consumers do not present their complain to the service providers or manufacturers, rather, they engage in negative attitudes which have no much influence and not seen or noticed by the service provider (Singh \& Wilkes, 1996).

Conversely, a consumer may choose to be responsive thereby answering back or reacting in eight different ways as illustrated in Figure 1. Responsive consumers are people that refused to live quietly with their discontent. This class of consumers sometimes involve third parties in order to achieve a desired result. Hawkins, Best, \& Coney (2004) stated that a dissatisfied consumer may complain to the service provider/manufacturer, stop buying that brand or from that store, warn friends and tell family members about it, complain to government agency, and take a legal action against the issue. Also, the consumer may write a letter of complain to the administration, 
make a verbal complain to management, and leave a note to request box. As it is, any of the behaviours chosen by an aggrieved consumer could result in losing sales or consumers by the firm (Healy, Kathleen, Les, \& Michael, 2001). This calls for MTN and other business organizations to quickly study the behaviours of their consumers and strategize on the best ways of addressing consumers' issues on services/products.

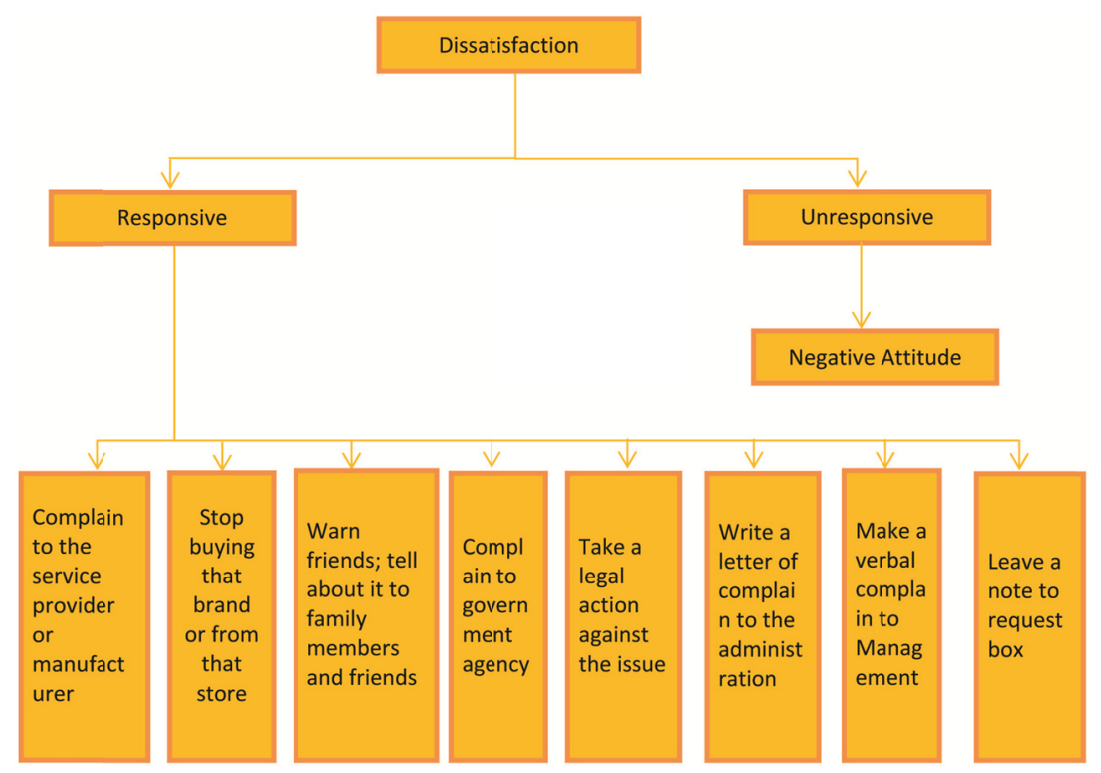

Figure 1. Consumer behavioural framework

Source: Hawkins, Best, \& Coney (2004).

\subsection{Dissatisfaction as a Determinant of $C C B$}

Over the past four decades, consumer satisfaction/dissatisfaction has received a substantial attention from scholars and practitioners. Some pragmatic studies have been conducted in order to narrow the gap in various consumer problems and reduce consumer switching (see Nimako \& Ntim, 2015; Kotler \& Keller, 2012; Day \& Landon, 1976). Consumer dissatisfaction is an individual's feeling of happiness or disappointment resulting from comparing a product's/service's perceived performance in relation to the expectation (Kotler, 2006). A study conducted by Liu, Kang, Bai, \& Zhang (2006) depicted that CCB is strongly related to consumer dissatisfaction and that dissatisfied consumers are more likely to vent their dissatisfaction through complaining. An example of the discontent or problem that could lead to different complain behaviours against business organizations is the unsubscribed charges of telecom service providers which some consumers regard as extortion since they did not request or make use of the service they are charged for. Consumers that experience such a problem tend to unleash several forms of CCB which will not benefit the firm or even spiral to litigation.

Correspondingly, the frustration suffered by some consumers due to poor service is an example of the dissatisfactions that could make them to express their anger with different types of CCB such as; boycott the service or negative word of mouth. Hence, Klein, Smith, \& John (2003) stated that boycott decision is triggered by a number of patterns that can be both expressive and instrumental. Boycott of MTN consumers is expressive as it is used to showcase the consumers' discontent. Service boycott by consumers becomes instrumental to firms only when they source for the cause of consumer dissatisfaction and address it as a response to decline in the number of loyal consumers.

\subsection{Demographic Variables as Determinants of Consumer Complain Behaviour}

The increasing rate of consumer complain has necessitated the need to assess the impacts of demographic variables on complain behaviour and consumer as a subject. Some researchers argued that demographic background (gender, age, education level, level of income, marital status and religion) of consumers predict their complain behaviour while others suggest that interpersonal factors have more impacts.

Gender: Some previous studies suggest that gender has no significant impact on consumer complain behaviour (Phau \& Sari, 2004; Liefeld, Edgecombe, \& Wolfe, 1975). Agbonifoh \& Edoreh (1986) also found that gender is insignificantly different in the level of awareness of rights among Nigerian consumers. Thus, men and women 
are equally aware or unaware of their rights as consumers. However, Keng, Richmond \& Han (1995); Heung \& Lam (2003) found that females are more likely to complain than males. These findings are contradicted by Manikas \& Shea (1997) who stated that male consumers complain more than females.

Age: Some studies found that younger consumers are more likely to complain than older consumers especially through a third party (Ngai et al., 2007; and Bearden, 1983). Inferences drawn from a related research in Singapore depict that complainers who choose public actions are older consumers (Phau \& Sari, 2004; Keng, Richmond, \& Han, 1995). In Nigerian context of consumers' complains, Agbonifoh \& Edoreh (1986) found that age is insignificantly different in the level of awareness of rights. Thus, young consumers are as knowledgeable of their rights as older consumers.

Religion: Religious affiliation is a significant predictor of consumers' evaluative criteria on certain shops or products/services and of differences in consumer buying behaviour (Essoo \& Dibb, 2004). Reidenbach \& Robin (1990) suggested that religion tends to influence ethical decision making, especially while making ethical judgment. The authors also stated that consumers consider many factors as justifications on their moral judgments and that the relative importance of these justifications is a function of the specific circumstances facing the consumer. They further opined that consumers with high religiosity are likely to abide by complete moral law and be less considerate of situational sways than those who are less religious.

Educational level: Educated consumers tend to be familiar with consumer knowledge and more likely to complain publicly (Heung \& Lam 2003; Bearden \& Mason, 1984; Day \& Landon 1976). Reiboldt (2003) suggests that education is positively related to complain behaviour. Consumers with higher levels of education are more likely to seek redress through a third party (Phau \& Sari, 2004; Lau \& Ng, 2001; Keng, Richmond, \& Han, 1995; Bearden, 1983). Jacoby \& Jaccard (1981) found that consumers with higher level of education are more likely to complain. These authors explained that consumers with higher level of education may be more empowered about their rights as consumers and the best way of seeking redress.

Income level: Referring to the predictive power of income on CCB, Hogarth, Hilgert, Kolodinsky, \& Lee (2001) stated that consumers who complain to third party agencies are likely to come from lower income background. The above finding is somehow contradicted with the findings of Singh (1989) which stated that higher income complainers with prior experience are likely to complain to third parties. Reiboldt (2003) opined that income is a variable that is almost inextricably related with complain behaviour. Consumers with higher income are more likely to seek third party redress (Phau \& Sari, 2004; Lau \& Ng, 2001; Keng, Richmond, \& Han, 1995; Bearden, 1983). Contrary to these findings, Azmi et al. (2016) found that monthly income level is insignificant to CCB.

Marital status: Hogarth, Hilgert, Kolodinsky, \& Lee (2001) believe that those who complain to third parties tend to be single. Perhaps, because they have ample time unlike the time crunch experienced by married consumers with children. Huefner \& Hunt (2000) argued that being married is positively related to happiness (i.e., forfeiting the product/service without complaining) in response to consumers' dissatisfaction. Married consumers tend to be exiting from companies or firms that they are dissatisfied with without voicing their discontent. However, a study of Singaporean consumers by Keng, Richmond, \& Han (1995) found no significant relationship between complain behaviour and marital status.

\section{Methodology}

\subsection{Design, Location and Sampling}

This is a quantitative study which employed a cross-sectional survey approach. The study population is the entire MTN consumers in Nigeria (over 61,200,000) but was represented with a sample from Festac town, Lagos state, Nigeria. Festac town Lagos was selected randomly in the list of locations that encompasses all the major ethnic groups in Nigeria. Again, it is a location that best explains Nigerian culture and business attitudes. The sample is derived from Cochran (1977) sample size calculation formula; i.e.: $\mathrm{n}=(\mathrm{t})^{2 *}(\mathrm{p})(\mathrm{q}) /(\mathrm{d})^{2}$.

$\mathrm{n}=$ Sample size, $\mathrm{t}=$ value of selected alpha level (1.96 i.e., $95 \%$ confidence level), $\mathrm{P}=$ estimated proportion of an attribute present in the population (.5), $\mathrm{q}=1-\mathrm{p}$ (estimate of the variance), and $\mathrm{d}=$ the acceptable margin of error or confidence interval (.05) in other words \pm 5 .

$\mathrm{n}=1.96^{2} \times .5 \times 1-.5 \div .05^{2}$

$\mathrm{n}=3.841 \times .25 \div .0025$

$\mathrm{n}=.960 \div .0025$

$\mathrm{n}=384.1$

Sample size $(\mathrm{n})=384.1 \approx 385$. 
The study employed stratified sampling technique. Stratified sampling technique is the process by which a researcher stratifies the population in such a way that the population within a stratum (group) is homogenous with respect to the characteristics on which it is being stratified (Ranjit, 2011). This is advantageous to the present study because, it allowed the researcher to extend the collection of data to three (3) parts of the study area through stratification, thereby encompassing a broader view of the subjects under study. Stratified sampling method does not entertain bias in selecting the respondents and makes data collection more robust.

\subsection{Data Collection}

Data were collected through survey with the use of self-administered questionnaires. This involved three (3) major areas around Festac town, namely; 24th road, 23rd road and 5th avenue which relied on the principle of stratification. The consumers around the above areas were given questionnaires to input their views.

\subsection{Inclusion/Exclusion Criteria}

The study was limited to MTN consumers only. Other mobile telecommunication network firms' consumers were not allowed to participate. Also, only MTN consumers with twelve months and above experiences with the firm's service were allowed to participate during the data collection. There was no gender or age limitation for the inclusion/exclusion criteria. More so, consumers that are not dissatisfied at all were not included in the sample. Thus, it was specifically for dissatisfied MTN consumers.

\subsection{Instrumentation}

The study instrument was a structured questionnaire which comprised closed-ended questions and tabulated statements that sought the respondent's opinion on CCB and dissatisfaction. The closed-ended questionnaire consisted of questions for consumer's demographic background. CCB was measured with 12-items in which 6-items were adapted from Singh (1988) while the other 6-items were developed by the researcher based on previous CCB literatures. Examples of the items are; "I will spread the news of my problem with MTN through social media", "I will subscribe/buy from another telecom network firm next time" and "I will make a verbal complain". CCB was measured on a five point Likert type scales, from $1=$ Very unlikely, $2=$ Unlikely, $3=$ Neutral, $4=$ Likely and $5=$ Very likely.

Dissatisfaction was measured with 12-items in which 7-item were adapted from a set of instruments developed and used by Oliver \& Westbrook (1981) to measure consumer satisfaction with cars and calculators. Other 5-items were developed by the researcher to compliment the adapted items in covering other dimensions of dissatisfaction in the present study. The respondents were asked how they felt after experiencing the situation with Mobile Telecommunication Network (MTN) services. The items were coded on a five point Likert scale ( $1=$ Strongly Disagree, $2=$ Disagree, $3=$ Neutral, $4=$ Agree and $5=$ Strongly Agree). Examples of the items are "MTN is one of the best telecom networks i could have bought", "I have truly enjoyed MTN network" and "I am satisfied with unsolicited messages with charges I receive from MTN".

The reliability of the study was ascertained with Cronbach alpha. The alpha value of CCB measuring instrument was .772; while that of dissatisfaction was .808. Relying on Hair et al. (1995), an alpha value greater than .70 is sufficient for most research purposes. Thus, the study instrument was found reliable. The study employed content validity; an expert in the field was used to validate the measuring instruments.

\subsection{Data Analysis}

The present study employed IBM SPSS version 22 to analyze the data. Descriptive statistics (frequency, percentage, mean and standard deviation) were used for describing demographic characteristics. Descriptive statistics were equally used in evaluating consumer complain behavior. Hierarchical regression was used to determine the major predictors of CCB.

\section{Results and Discussions}

\subsection{Sample Characteristics}

The respondents' background information has been summarised in Table 1. The results showed that higher percentages of respondents of the present study are males as they are more than half of the overall sample which constitutes $224(58.2 \%)$ males. Female respondents are $161(41.8 \%)$. The age range of 18-27 years is higher in number as it accounts for $47.0 \%$ of the respondents, followed by $28-47$ years which constitutes $41.0 \%$. Respondents whose age is more than 47 years comprised of $11.9 \%$ which is the smallest age category. About $74.3 \%$ of the respondents attained tertiary education, followed by secondary education which constitutes of $22.9 \%$. Respondents with primary education comprised of $2.1 \%$ while respondents that never attended school accounted for $.8 \%$ which shows that very few respondents did not attend schools and, majority of the 
respondents are educated to tertiary level.

Also, $63.9 \%$ of the respondents are single, $35.6 \%$ are married while $.5 \%$ are either divorced or religious people that will not marry. This indicates that more than half of the respondents of the present study are single. In addition, $57.1 \%$ of the respondents are Christians, while $42.9 \%$ are Muslims. This shows that the study location is predominantly Christians and Muslims as no respondent was identified to be part of any religion other than the above two. It further indicates that there are more Christian respondents than Muslims in the present study. Furthermore, less than half of the respondents earn below $\# 18,000$ per month as it comprised $44.2 \%$, followed by $\# 18,000-\# 75,000$ which recorded $30.9 \%$. Respondents with income level of more than $\# 75,000$ per month constituted $24.9 \%$ which implies that majority of the respondents are low income earners.

\subsection{Evaluation of MTN Consumers' Complain Behaviour}

As summarised in Table 1, the evaluation of MTN consumer's behaviour is classified into passive and active categories. Out of the overall respondents (385) of the present study, $250(64.9 \%)$ which constitutes more than half of the respondents possess passive behaviours. The remaining $135(35.1 \%)$ respondents possess active behaviours. Passive behaviour entails a consumer to continue living with a defective product or poor service experience without complaining officially. Active behaviour refers to a consumer voicing out his/her discontent in a marketing exercise either by him/herself or through a third party. The mean value (34.1) fell within the passive score range, signifying that most MTN consumers in Nigeria do not complain. They are more passive than active thus; somehow loyalists of MTN as the firm still maintain the largest share of the Nigerian telecom market. Although some aggrieved consumers exit the firm's service, but their exit is insignificant, hence the firm's market share does not decline.

Table 1. Evaluation of MTN consumers' complain behaviour

\begin{tabular}{llllll}
\hline Category & Score range & Frequency & Percentage (\%) & Mean & SD \\
\hline Passive & $12-36$ & 250 & 64.9 & 34.1 & 8.9 \\
Active & $37-60$ & 135 & 35.1 & & \\
Total & & 385 & 100.0 & & \\
\hline
\end{tabular}

Source: Survey 2016.

\subsection{Effects of Demographic Variables and Dissatisfaction on $C C B$}

Hierarchical regression was used to determine the unique contributions of the demographic variables and dissatisfaction on complain behaviour as depicted in Table 2. Preliminary analyses were conducted to ensure no violation of the assumptions of normality, linearity, multicollinearity and homoscedasticity. The six demographic variables were entered into the regression model as independent variables at the first step to predict complain behaviour. The regression result indicated that the six demographic variables explained $4.9 \%$ variance on complain behaviour. The low variance explained by the selected demographic variables conforms to Ridzwan et al. (2013) findings which concluded that interpersonal variables predicts complain behaviour more. Only religion $(\beta=.15, \mathrm{p}<.01)$, and level of income $(\beta=.12, \mathrm{p}<.05)$ made unique significant contributions to complain behaviour. Sequel to the significance of religion and level of income only, the first $\mathrm{H} 0$ is accepted. Demographic variables have no significant effect on CCB. The result on the significant contribution of religion to CCB is supported by Esso \& Dibb (2004) where they found religious affiliation as a significant predictor of CCB. Also, the significant contribution of income level result is in tandem with the findings of Reiboldt (2003).

Table 2. Summarised effects of demographic variables and dissatisfaction on complain behaviour ( $\mathrm{n}=383$ )

\begin{tabular}{llllllllll}
\hline Steps & Variables & $\mathrm{B}$ & $\mathrm{S} . \mathrm{E}$ & $\beta$ & $\mathrm{p}$ & $\mathrm{VIF}$ & $\mathrm{F}$ & $\mathrm{R}^{2}$ & $\Delta \mathrm{R} 2$ \\
\hline 1 & - & - & - & - & - & - & $3.263^{* * *}$ & .049 & - \\
& Gender & -1.030 & .897 & -.058 & .252 & 1.015 & - & - & - \\
& Age & 1.075 & .857 & .084 & .211 & 1.785 & - & - & - \\
& Educational level & -.943 & .810 & -.059 & .245 & 1.011 & - & - & - \\
& Current marital status & .593 & 1.151 & .033 & .607 & 1.636 & - & - & - \\
& Religion & 2.675 & .896 & .152 & .003 & 1.020 & - & - & - \\
& Level of income & 1.281 & .651 & .119 & .050 & 1.441 & - & - & - \\
2 & - & - & - & - & - & - & $9.449 * * *$ & .150 & .100 \\
& Dissatisfaction & -.330 & .050 & -.325 & .000 & 1.049 & - & - & - \\
\hline
\end{tabular}

Note. $\mathrm{B}=$ unstandardized beta, $\beta=$ standardized beta, $\mathrm{p}=$ significant level, $\mathrm{F}=\mathrm{F}$ statistics, $\mathrm{R}^{2}=$ variance, $\Delta \mathrm{R} 2=$ change in variance, ${ }^{* * *}=$ model significance $(\mathrm{p})<.001$. 
The non-significant and unique contribution of four demographic variables implies that demographic variables have limited influence towards consumers' choice of action. Hence, gender's non-significant contribution in the present study is supported by Phau \& Sari (2004); age's non-significant contribution conforms to Agbonifoh \& Edorah (1986) where they found that age category does not predict the complain behaviour of Nigerian consumers. The non-significant contribution of educational level is contrary to the findings of Reiboldt (2003) which stated that educational level is positively related to complain behaviour. Marital status as a non-significant contributor of CCB in the present study is supported by Keng, Richmond, \& Han (1995). The result is an indication that complain behaviour is not fully dependent on demographic background. Pertinent to note is that religion and level of income are strong predictors of consumer's choice of action in a dissatisfaction scenario as can be seen from their significant contributions towards complain behaviour. Mobile Telecommunication Network (MTN) consumers may be propelled into active or passive complain behaviours based on factors other than demographic variables. For instance, a consumer may decide to complain in a particular way bearing in mind the economy of the state and the firm's image but undermined by his/her religion and level of income.

Similarly, dissatisfaction was entered into the model at the second step. The regression result indicated that the model explained $15 \%$ variance on complain behaviour, F $(7,357)=9.45, \mathrm{p}<.001$. Dissatisfaction explained an additional $10 \%$ of the variance on complain behaviour after controlling for demographic variables in the model, $\mathrm{R}^{2}$ change $=.10, \mathrm{~F}$ change $(1,375)=44.32, \mathrm{p}<.001$. Only three control measures were statistically significant, with dissatisfaction recording a higher beta value $(\beta=-.33, p<.001)$ than religion $(\beta=.12, p<.05)$, and level of income $(\beta=.11, \mathrm{p}<.05)$. Based on the findings, the second $\mathrm{H}_{0}$ is rejected. Dissatisfaction has a significant effect on CCB after controlling the effects of demographic background.

Dissatisfaction made a significant unique contribution on complain behaviour after the effects of demographic variables are controlled. This implies that dissatisfaction leads MTN consumers to complain in various ways irrespective of their background. This result is supported by the findings of Singh (1990) which stated that demographic variables offer limited explanatory power in explaining the differences in consumer complain behaviour. Also, the result is in tandem with the findings of Kraft (1977) on consumer perceptions of business fraud.

Inferences from the study have shown dissatisfaction as a hyper predictor of $\mathrm{CCB}$ irrespective of demographic background. Thus, it strengthens the findings of Keaveny (1995) in which the three major causes of CCB were identified. Keaveny (1995) named the causes as; core service failure, service encounter failure, and response to failures. It is notable that service encounter failure is prevalent with MTN services which as a result aggravate the consumers more.

In addition, $\mathrm{CCB}$ tends to spiral beyond the firm's expectation in cases of consumers with past experience of dissatisfaction. Moreover, considering the income level of MTN consumers, CCB is likely to take a different shape in cases of low income class consumers as they attach more importance to any of their expenses. Religion is however, another predictor of CCB given the same magnitude of undiluted message disseminated in the two dominant religions in respect to philosophy of business across Nigeria.

\section{Conclusions and Recommendations}

\subsection{Conclusions}

Having delineated on MTN consumers' complain behaviour, the findings revealed that more than $64 \%$ of MTN consumers are passive complainers while slightly above $35 \%$ are active complainers. This portends a potential negative word of mouth from the passive complainers. Presumably, the low level of active complainers among MTN consumers jeopardised the chances of knowing the cause of consumers' discontent which would have helped to unravel the unhealthy situation. Thus, extending the likelihood of negative word of mouth against MTN by affected consumers. The study also highlighted the impacts of consumers' religion and level of income as significant background variables. It also showed dissatisfaction as a stronger predictor of CCB more than background variables.

Theoretically, it implies that high level of passive complain behaviour is detrimental to business organisations. In addition, religion and level of income are predictors of consumer complain behaviour. Also, dissatisfaction is an insubvertable factor of CCB. These assertions are based on the significant contributions of the above variables in the present study. The study opines that complain behaviour is determined by consumers' religion, level of income and dissatisfaction.

Conversely, it practically implies that passive complainers will assassinate the image of the firm in their discontent. Again, religious consumers tend to complain more than non-religious ones given their attachment to 
religious affiliations in making ethical and complaining decisions. Consumers with high income level may channel their complains to a different direction from those with low income level. It means that both high and low income earners will complain as a response to ill-service or defective product. Furthermore, dissatisfied consumers will complain irrespective of their background. This, in addition, implies that dissatisfied consumers will complain beyond level of income borderlines and religious commitments in response to organisational service flaws.

The present study has emphasized on CCB with some limitations. Unfortunately, it could not investigate MTN consumers' complain behaviours more in-depthly due to the quantitative approach employed in the study. Thus, the study encountered methodological limitation. Other than that, high religiosity and many job opportunities which influence income level in Lagos could as well offer a different result if extended to other parts of Nigeria. As such, the generalization power of the findings is limited. The reason is that all the data were collected within a suburb of Lagos state, and there is a tendency of consumers in other parts of Lagos, cities in Nigeria or in the villages to adopt different types of complain behaviour which could reshape the high passive result.

\subsection{Recommendations}

The conclusions obtained from the present study are limited to some extent which requires further research. Consequently, further studies should be conducted with mixed method for more in-depth findings on the complain behaviours of MTN consumers. Future studies should investigate the relationship between CCB, dissatisfaction, religion and income level of consumers. In addition, the effects of complaining intention, perceived possibility of success and attitude towards complaining on CCB should be tested together with dissatisfaction and demographic variables. There is also need for a broader study that will encompass other cities and states in order to increase the generalization power of the findings.

Business organizations with the vision of gaining consumers' trust, loyalty and possibly increase their consumers as a step to extending their market share should;

(i) Encourage consumers to exhibit active complain behaviour. As it is, firms with market dominance philosophy should be on the forefront to this campaign. Hence, it remains a veritable avenue of unmasking the causes, types and levels of consumers' dissatisfaction.

(ii) Attention should be given to consumers' religiosity and income levels since these two variables influence CCB. MTN and other firms should therefore, establish platforms that can harmoniously attend to highly religious consumers' complain.

(iii) Business organizations should eradicate dissatisfaction among their consumers as a consolidating mechanism to the efforts of active complainers. MTN and other firms in this situation should upgrade their network facilities, adjust their call tariffs and operate consumer oriented policies. Executing these suggestions will not only reduce consumers' problems, rather, it will foster loyalty, trust and continued patronage between firms and consumers.

\section{References}

Agbonifoh, B., \& Edoreh, P. (1986). Consumer awareness and complaining behavior. European Journal of Marketing, 20(6), 43-49. https://doi.org/10.1108/EUM0000000004655

Anthony, F. M. (2012). Customer complaint behaviour towards mobile telephony services - cases of mtn and tigo Ghana. International Journal of Business and Social Research (IJBSR), 2(4).

Azmi, M., Aini, M. S., Elistina, A. B., Nur, L. K., \& Zarina, A. M. (2016). Determining the Income Differences and Complaint Behaviour among Automobile Repairs and Service Consumers in Shah Alam, Malaysia. Fifth international conference on marketing and retailing (5th incomar).

Bard, T. (2008). Customer Complaint Behaviour in Service. Dissertation, Karlstad University Studies. Retrieved from http://www.diva portal.org/smash/get/diva2:5576/ FULLTEXT01.pdf

Bearden, W. O. (1983). Profiling consumers who register complains against auto repair services. The Journal Of Consumer Affairs, 17(2), 315-335. https://doi.org/10.1111/j.1745-6606.1983.tb00306.x

Bearden, W. O., \& Mason, J. (1984). An investigation of influences on consumer complain reports. In T. Kinnear (Ed.), Advances in Consumer Research, 11. Retrieved from http://www.acrwebsite.org/volumes/5933/volumes/v11/NA-11

Day, R. L., \& Landon, E. L. Jr. (1976). Collecting comprehensive consumer complaining data by survey research. In B. A. Beverlee (Ed.), Advances in consumer research (pp. 263-268).

Donu, K. (2011). Vanguard newspaper; Communication problems. Retrieved from 
http://www.vanguardngr.com/2011/04/communication-problems/

Essoo, N., \& Dibb, S. (2004). Religious Influences on Shopping Behaviour: An Exploratory Study. Journal of Marketing Management, 20, 683-712. https://doi.org/10.1362/0267257041838728

Grace, S. H. C., Chun-Hsuan, A. H., \& Ada, L. Y. L. (2016). Exploration of Customer Complaint Behaviour toward Asian Full-Service Restaurants. International Journal of Marketing Studies, 8(2). http://dx.doi.org/10.5539/ijms.v8n2p46

Hair, J. F., Black, W. C., Anderson, R. E., \& Tatham, R. L. (1995). Multivariate data analysis with readings (4th ed.). Englewood Cliffs, NJ: Prentice-Hall Inc.

Hawkins, D. I., Best, R. J., \& Coney, K. A. (2004). Consumer behaviour: building marketing strategy (9th ed.). McGraw-Hill Irwin: New York.

Healy, M., Kathleen. H., Les, B., \& Michael, G. (2001). The Old, the New and the Complicated: A Triology of Marketing Relationships. European Journal of Marketing, 35(1/2), 184. https://doi.org/10.1108/03090560110363418

Heung, V., \& Lam, T. (2003). Customer complaint behaviour towards hotel restaurants services. International Journal of Contemporary Hospitality $\quad$ Management, $\quad 15(5), \quad 283-289$. https://doi.org/10.1108/09596110310482209

Hogarth, M. J., Hilgert, M. A., Kolodinsky, J. M., \& Lee, J. (2001). Problems with credit cards: An exploration of consumer complaining behaviours. Journal of Consumer Satisfaction, Dissatisfaction and Complaining Behaviour, 14, 88-107.

Huefner, J. C., \& Hunt, H. K. (2000). Consumer retaliation as a response to dissatisfaction. Journal of Consumer Satisfaction, Dissatisfaction and Complaining Behaviour, 13, 61-82.

Jacoby, J., \& Jaccard, J. J. (1981). The Sources, Meaning and Validity of consumer complaint Behaviour. Journal of Retailing, 57(3), 4-23.

Keaveney, S.M. (1995). Customer Switching Behaviour in Service Industries: An explanatory Study. Journal of Marketing, 50(2), 71-82. https://doi.org/10.2307/1252074

Keng, K. A., Richmond, D., \& Han, S. (1995). Determinants of consumer complaint behaviour: A study of Singapore consumers. Journal of International Consumer Marketing, 8(2), 59-76. http://dx.doi.org/10.1300/J046v08n02_05

Klein J. G., Smith, N. C., \& John, A. (2003). Why We Boycott: Consumer Motivations for Boycott Participation and Marketers Responses. Centre for Marketing, London Business School, 1-39. Retrieved from http://facultyresearch.london.edu/docs/03-702.pdf

Kotler, P., \& Keller, K. (2006). Marketing Management (12th ed.). New Jersey: Pearson Education Inc.

Kotler, P., \& Keller, K. (2012). Marketing Management (14th ed.). Upper Saddle River, NJ: Prentice Hall.

Kraft, F. B. (1977). Consumer Perceptions of Business Fraud: A Key Variable in Complaint and Repatronage Behaviour. Paper presented at the South-western Marketing Meetings, New Orleans, March 23-26.

Lau, G. T., \& Ng, S. (2001). Individual and situational factors influencing negative word of mouth behaviour. Revue Canadienne des Sciences de l'Administration, 18(3), 163-178. https://doi.org/10.1111/j.1936-4490.2001.tb00253.x

Leifeld, J. P., Edgecombe, F. H. C., \& Wolfe, L. (1975). Demographic Characteristics of Canadian Consumer $\begin{array}{llllll}\text { Complainers. The Journal of } & \text { Consumer } & \text { 73-80. }\end{array}$ https://doi.org/10.1111/j.1745-6606.1975.tb00550.x

Liu, J., Kang J., Bai, Y., \& Zhang, X. (2006). The study of customer complaints management based on system dynamics: modelling and simulation. Proceedings of the fifth international conference on machine learning and cybernetics, Dalian.

Manikas, P., \& Shea, L. (1997). Hotel complaint behaviour and resolution: a content analysis. Journal of Travel Research, 36(2), 68-73.

Mowen, J. (1993). Consumer Behaviour (p. 467). Ney York: Macmillan publishing company.

Ngai, E. W. T., Heung, V. C. S., Wong, Y. H., \& Chan, F. K. Y. (2007). Consumer complain behaviour of Asians and non-Asians about hotel services: An Empirical analysis. European Journal of Marketing, 41(11/12), 
1375-1391. htt://dx.doi.org/10.1108/03090560710821224

Nimako, S. G. (2012). Customer Dissatisfaction and Complaining Responses Towards Mobile Telephony Services. The African Journal of Information Systems, 4(3). Retrieved from http://digitalcommons.kennesaw.edu/ajis/vol4/iss3/1

Nimako, S. G., \& Ntim, B. A. (2015). Modelling the Antecedents and Consequence of Consumer Switching Intentions in Ghana Mobile Telecommunication Industry. International Journal of Business and Emerging Markets, 7(1), 37-75. https://doi.org/10.1504/IJBEM.2015.066093

Oliver, R. L., \& Westbrook, R. A. (1981). Developing better measures of consumer Satisfaction: some preliminary results. Advances in Consumer Research, 8, 94-99. Retrieved from http://acrwebsite.org/volumes/9791/volumes/v08/NA-08

Phau, I., \& Sari, R. P. (2004). Engaging in complaint behaviour: an Indonesian perspective. Marketing Intelligence and Planning, 22(4), 407-426. http://dx.doi.org/10.1108/02634500410542770

Ranjit, K. (2011). Research methodology. A step by step guide for beginners (3rd ed.). New York: SAGE publication limited.

Reiboldt, W. (2003). Factors that Influence a Consumer Complainer's Rating of Service Received from a Third Party Complaint-Handling Agency-The Los Angeles Department of Consumer Affairs. Journal of Consumer Satisfaction, Dissatisfaction and Complaining Behavior, 16, 166-177.

Reidenbach, R. E., \& Robin, D. P. (1990). Toward the Development of a Multidimensional Scale for Improving Evaluations of Business Ethics. Journal of Business Ethics, 9(8), 639-653. https://doi.org/10.1007/BF00383391

Rizwan, M., Khan, A., Saeed, I., Shah, K., Azhar, N., \& Anam, W. (2013). Determinants of Customer Complaining Behaviour. International Journal of Research in Computer Applications and Management, 3(3), 119-124.

Sergio, B. (2007). Consumer complain behaviour (CCB); A literature review. Retrieved from http://dspace-unipr.cineca.it/bitstream/1889/1178/1/Butelli\%2520Literature\%2520review.pdf

Singh, J. (1988). Consumer Complaint Intentions and Behaviour: Definitional and Taxonomical Issues. Journal of Marketing, 52, 93-107. https://doi.org/10.2307/1251688

Singh, J. (1989). Determinants of consumers' decisions to seek third party redress: An empirical Study of dissatisfied patients. The Journal of Consumer Affairs, 23(2), 329-363. https://doi.org/10.1111/j.1745-6606.1989.tb00251.x

Singh, J. (1990). Identifying consumer dissatisfaction response style: An agenda for future research. European Journal of Marketing, 24(6), 55-72. https://doi.org/10.1108/03090569010140516

Singh, J., \& Wilkes, R. E. (1996). When consumers complain: A path analysis of the key antecedents of consumer complaint response estimates. Journal of the Academy of Marketing Science, 24(4), 350-374. https://doi.org/10.1177/0092070396244006

Timothy, E. M. (2015). Daily post newspaper. Reps order NCC to stop unsolicited caller tunes, messages. Retrieved from http://dailypost.ng/2015/08/12/reps-order-ncc-to- stop-unsolicited-caller-tunes-messages

\section{Copyrights}

Copyright for this article is retained by the author, with first publication rights granted to the journal.

This is an open-access article distributed under the terms and conditions of the Creative Commons Attribution license (http://creativecommons.org/licenses/by/4.0/). 